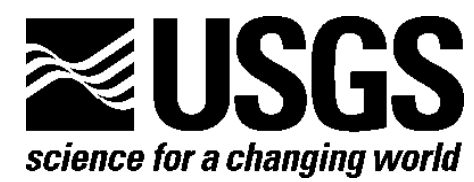

\title{
Emergency Assessment of Post-Fire Debris-Flow Hazards for the 2013 Powerhouse Fire, Southern California
}

By Dennis M. Staley, Greg M. Smoczyk, and Ryan R. Reeves

Open-File Report 2013-1248

U.S. Department of the Interior

U.S. Geological Survey 


\section{U.S. Department of the Interior \\ SALLY JEWELL, Secretary}

\section{U.S. Geological Survey \\ Suzette M. Kimball, Acting Director}

U.S. Geological Survey, Reston, Virginia: 2013

For more information on the USGS-the Federal source for science about the Earth,

its natural and living resources, natural hazards, and the environment-visit

http://www.usgs.gov or call 1-888-ASK-USGS

For an overview of USGS information products, including maps, imagery, and publications, visit $h$ ttp://www.usgs.gov/pubprod

To order this and other USGS information products, visit $h$ ttp://store.usgs.gov

Suggested citation:

Staley, D.M., Smoczyk, G.M., and Reeves, R.R., 2013, Emergency assessment of post-fire debris-flow hazards for the 2013 Powerhouse fire, southern California: U.S. Geological Survey Open-File Report 2013-1248, 13 p., 3 plates, http://pubs.usgs.gov/of/2013/1248/.

Any use of trade, firm, or product names is for descriptive purposes only and does not imply endorsement by the U.S. Government.

Although this information product, for the most part, is in the public domain, it also may contain copyrighted materials as noted in the text. Permission to reproduce copyrighted items must be secured from the copyright owner. 


\section{Contents}

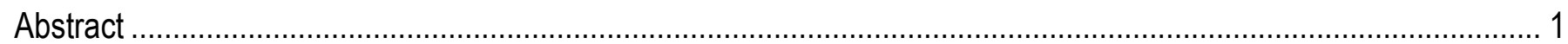

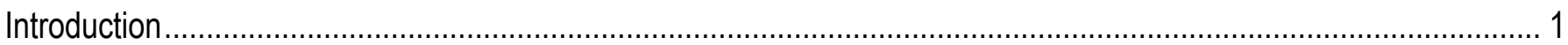

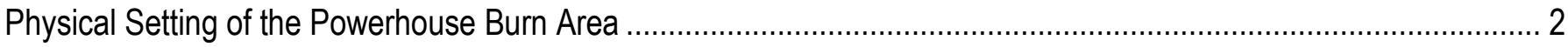

Methods Used To Estimate Debris-Flow Hazards ................................................................................... 5

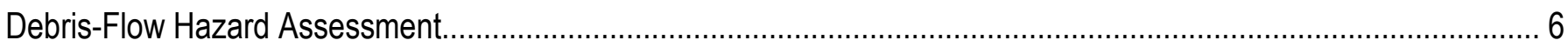

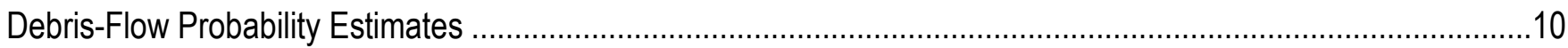

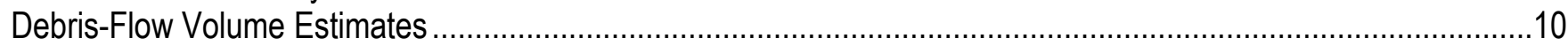

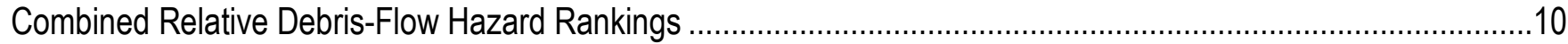

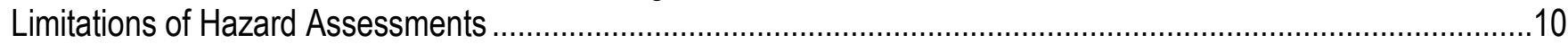

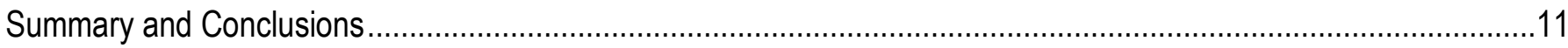

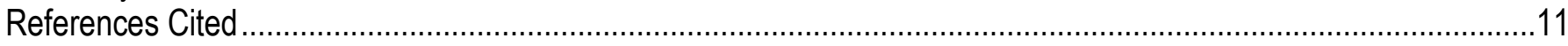

\section{Figures}

Figure 1. Overview map of the Powerhouse fire burn area near Lancaster, California, USA................................. 3

Figure 2. Burned Area Reflectance Classification (BARC) burn severity map of the Powerhouse fire burn

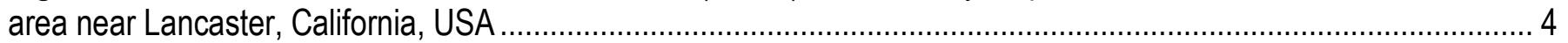

\section{Table}

Table 1. Basin outlet locations (UTM Zone 11 NAD83, Meters), morphometric variables, rainfall characteristics and model predictions for the 73 defined watersheds in the Powerhouse burn area

\section{Plates}

Plate 1. Estimated probability of post-fire debris flows in the area burned by the 2013 Powerhouse fire, southern California. link

Plate 2. Estimated volume of post-fire debris flows in the area burned by the 2013 Powerhouse fire, southern California. link

Plate 3. Combined post-fire debris-flow hazard in the area burned by the 2013 Powerhouse fire, southern California. link 


\section{Conversion Factors and Datums}

\begin{tabular}{lcl}
\hline \multicolumn{1}{c}{ Multiply } & \multicolumn{1}{c}{ By } & To obtain \\
\hline millimeter $(\mathrm{mm})$ & 0.03937 & inch (in.) \\
meter $(\mathrm{m})$ & 3.281 & foot $(\mathrm{ft})$ \\
kilometer $(\mathrm{km})$ & 0.6214 & mile $(\mathrm{mi})$ \\
\hline \multicolumn{3}{c}{ Area } \\
\hline hectare $($ ha) & 2.471 & acre \\
square kilometer $\left(\mathrm{km}^{2}\right)$ & 247.1 & acre \\
square kilometer $\left(\mathrm{km}^{2}\right)$ & 0.3861 & square mile $\left(\mathrm{mi}^{2}\right)$ \\
square meter $\left(\mathrm{m}^{2}\right)$ & 10.76 & square foot $\left(\mathrm{ft}^{2}\right)$ \\
\hline \multicolumn{3}{c}{ Volume } \\
\hline cubic meter $\left(\mathrm{m}^{3}\right)$ & 35.31 & cubic foot $\left(\mathrm{ft}^{3}\right)$ \\
\hline \multicolumn{3}{c}{ Flow rate } \\
\hline millimeter per hour $(\mathrm{mm} / \mathrm{h})$ & 0.03937 & inch per hour $(\mathrm{in} / \mathrm{h})$ \\
\hline
\end{tabular}

Vertical coordinate information is referenced to the North American Vertical Datum of 1988 (NAVD 88).

Horizontal coordinate information is referenced to the North American Datum of 1983 (NAD 83). 


\title{
Emergency Assessment of Post-Fire Debris-Flow Hazards for the 2013 Powerhouse Fire, Southern California
}

\author{
By Dennis M. Staley, Greg M. Smoczyk, and Ryan R. Reeves
}

\begin{abstract}
Wildfire dramatically alters the hydrologic response of a watershed such that even modest rainstorms can produce dangerous flash floods and debris flows. Existing empirical models were used to predict the probability and magnitude of debris-flow occurrence in response to a 10-year recurrence interval rainstorm for the 2013 Powerhouse fire near Lancaster, California. Overall, the models predict a relatively low probability for debris-flow occurrence in response to the design storm. However, volumetric predictions suggest that debris flows that occur may entrain a significant volume of material, with 44 of the 73 basins identified as having potential debris-flow volumes between 10,000 and 100,000 cubic meters. These results suggest that even though the likelihood of debris flow is relatively low, the consequences of post-fire debris-flow initiation within the burn area may be significant for downstream populations, infrastructure, and wildlife and water resources. Given these findings, we recommend that residents, emergency managers, and public works departments pay close attention to weather forecasts and National-Weather-Service-issued Debris Flow and Flash Flood Outlooks, Watches, and Warnings and that residents adhere to any evacuation orders.
\end{abstract}

\section{Introduction}

The occurrence of debris flows in response to high-intensity rainfall is well documented in recently burned areas of southern California (for example, Eaton, 1935; Campbell, 1975; McPhee, 1989; Cannon and others, 2008; 2010; 2011; Cannon and DeGraff, 2009; Kean and others, 2011; Staley and others, in press). Two recent examples highlight the destructive nature of post-fire debris flows. On December 25, 2003, a high-intensity rainstorm initiated debris flows within the Grand Prix and Old burn areas and killed 16 people near San Bernardino, California (Calif.). On February 6, 2010, debris flows produced in the Station burn area overtopped sediment-retention basins and damaged or destroyed 46 homes in La Crescenta, Calif. These events provide sobering examples of the threat that post-fire debris flows pose to lives, properties, infrastructure, and important natural resources within and downstream of recently burned steeplands.

Wildfire causes numerous changes to the vegetative characteristics and physical and chemical properties of the soil within a burn area. Reduction in vegetation cover on hillslopes increases the likelihood of soil erosion during rainfall and runoff. Wildfire has also been demonstrated to increase the rate of runoff production by enhancing hydrophobicity in soils through chemical changes and by introducing ash into the soil column (Shakesby and Doerr, 2006; Gabet and Sternberg, 2008; Larsen and others, 2009). These changes ultimately contribute to increases in the rate of runoff and sediment production during rainfall. The enhanced runoff response initiates floods and debris flows even during relatively minor rainstorms (Shakesby and Doerr, 2006; Cannon and others, 2008). Post-fire debrisflow hazards further increase in likelihood when the physical and chemical changes introduced during 
wildfire are combined with steep slopes and an abundant supply of sediment. Given the relatively steep terrain, severity of the wildfire, and proximity of local population and infrastructure, there is an elevated risk of post-fire debris-flow hazards within and downstream of the Powerhouse fire burn area. The purpose of this report is to provide a preliminary assessment of the likelihood and potential magnitude of post-fire debris flows in the area burned by the 2013 Powerhouse fire in Los Angeles County, Calif. We use empirical methods that have been previously applied in this region of southern California (for example, Cannon and others, 2007; 2009) to estimate (1) the probability of debris-flow occurrence in response to a storm of a given duration and intensity, (2) the predicted volume of material transported and deposited by a debris flow in response to a storm with a 10-year (yr) recurrence interval, and (3) a combined relative hazard ranking that incorporates the results of the probability and volume models.

\section{Physical Setting of the Powerhouse Burn Area}

The Powerhouse fire burned 122.5 square kilometers $\left(\mathrm{km}^{2}\right)(30,275$ acres $)$ of mountainous terrain in northern Los Angeles County near Lancaster, Calif. (inciweb.org, 2013) from May 30th through June 10th, 2013 (fig. 1). The communities most affected by this event include the towns of Elizabeth Lake and Lake Hughes and private properties within Elizabeth Lake Canyon, such as the Cottonwood Campground and the Canyon Creek Sports Camp. The Powerhouse fire damaged or destroyed 24 homes, all of which were located near Lake Hughes.

The Powerhouse burn area occupies mostly mountainous terrain, where elevations range from 630 meters $(\mathrm{m})$ to $1,410 \mathrm{~m}$, with an average slope of 32 percent. The rock type in the burn area is predominantly gneiss and granodiorite, with some sandstone and alluvium units (Jennings and Strand, 1969). These lithologies weather to produce coarse sandy loam soils. The burn area also contains numerous faults, including approximately 5 kilometers $(\mathrm{km})$ of the San Andreas fault zone, along which the towns of Elizabeth Lake and Lake Hughes are situated. A majority of the area was burned at moderate (56 percent) and high (10 percent) severity (fig. 2) (Remote Sensing Applications Center, 2013). Areas of moderate and high burn severities fall primarily in the southern portion of the burn area where the topography contains steeper slopes and more dense vegetation. The northern extent of the burn area, which contains portions of the Portal Ridge hills, the San Andreas fault zone, and the Antelope Valley, was burned primarily at moderate or low severity.

The Powerhouse burn area is located in inland Los Angeles County and has lesser rainfall than other debris-flow prone locations, such as the San Gabriel, San Bernardino or Santa Monica mountains. Precipitation frequency estimates for the burn area indicate that there is 10-percent likelihood in any given year (that is, a 10 -yr storm event) that 30-minute (min) rainfall accumulations within the burn area will range between 13.6 and 21.2 millimeters $(\mathrm{mm})(0.5$ and 0.8 inches [in]) (Bonnin and others, 2006). These estimates suggest that it would take a relatively large rainstorm (that is, greater than a 10-yr recurrence interval) to produce rainfall rates that have been observed to initiate post-fire debris flows in the region (Cannon and others, 2008; Staley and others, in press). 


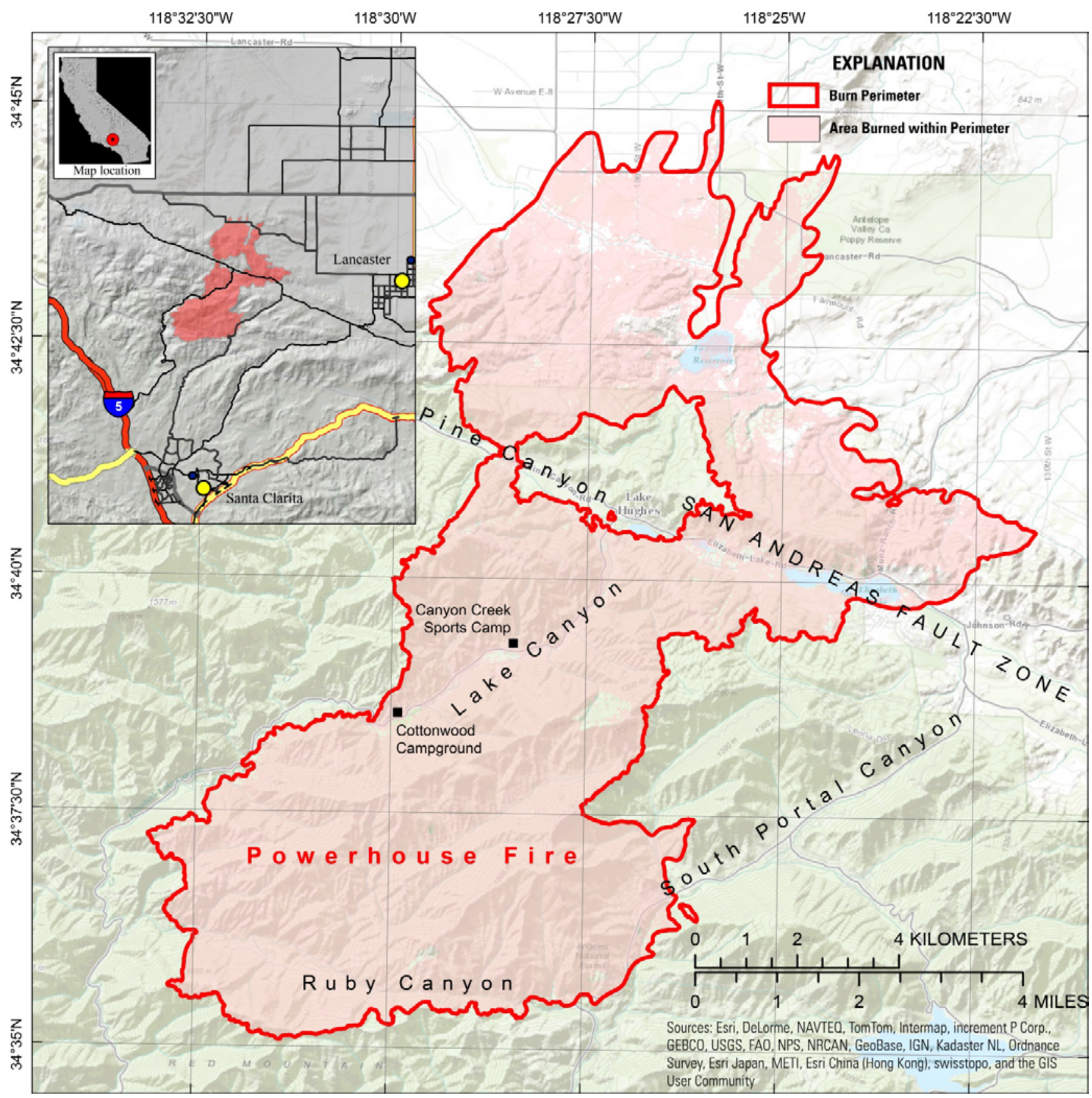

Figure 1. Overview map of the Powerhouse fire burn area near Lancaster, California. 


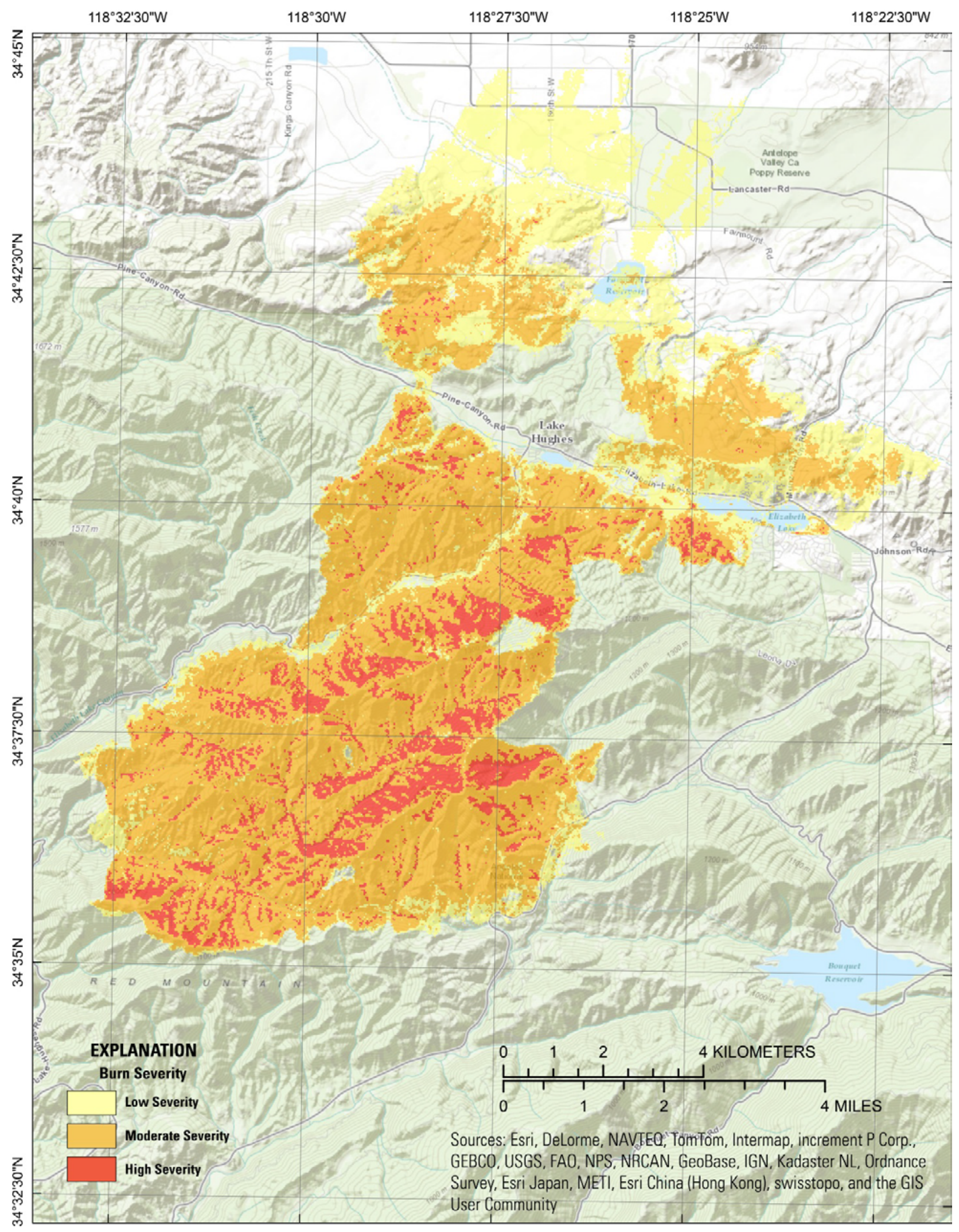

Figure 2. Burned Area Reflectance Classification (BARC) burn severity map of the Powerhouse fire burn area near Lancaster, California, USA. 


\section{Methods Used To Estimate Debris-Flow Hazards}

The preliminary hazard assessment relies upon two empirical models to estimate the probability, volume, and combined relative hazard ranking of debris flows for selected drainage basins within the Powerhouse fire burn area in response to a design storm. In this case, we use a rainstorm with a 10-yr recurrence interval for the design storm. We selected this storm frequency and magnitude as it represents a relatively large magnitude (in terms of total accumulation and peak storm intensities), but still somewhat common rainstorm. The empirical models are based upon historical debris-flow occurrence data, rainfall storm conditions, terrain and soils information and burn severity data from recently burned areas in southern California. The database consists of 1,748 records from 20 burn areas from the years 2003-2010.

In this study, the drainage basin scale was used to calculate post-fire debris-flow probability, volume, and combined hazards. Here, 73 basins were defined by analyzing elevation data from $10 \mathrm{~m}$ USGS digital elevation models (DEMs). Measures of the soil K-Factor within each basin were obtained from the State Soil Geographic (STATSGO) database (Schwartz and Alexander, 1995). The soil K-Factor represents a relative index of the susceptibility of bare soil to particle detachment and transport by rainfall (Schwartz and Alexander, 1995). If more than one soil unit occurred within a given basin, a spatially weighted average of the soil variable values was calculated. The K-Factor of soils in basins burned by the Powerhouse covered a narrow range from 0.18-0.29.

The probability estimates are based upon a logistic regression model derived from a southernCalifornia-specific database (Rupert and others, 2008), updated in 2011 to include basin-response information from the fires of 2007-2010 (Susan Cannon, 2011, unpublished data). This model is designed to predict the probability of debris-flow occurrence at a basin outlet in response to a given storm by combining the following two equations:

$$
P=e^{x} /\left(1+e^{x}\right)
$$

where:

$P$ is the probability of debris-flow occurrence in fractional form and

$e^{x}$ is the exponential function where $e$ represents the mathematical constant 2.718 . Equation 2 is used to calculate $x$ :

$$
\begin{aligned}
& x=-5.8+\left(0.002 \times \text { ElevRange }^{2}\right)+\left(0.022 \times \text { pct }_{\text {B50 }}\right)+\left(0.028 \times \text { pct }_{\text {high }}\right)+ \\
& (7.017 \times \text { Kfact })+(0.017 \times \text { r } 30)(2)
\end{aligned}
$$

where:

ElevRange is the range (maximum elevation-minimum elevation) within the watershed (in meters), $p c t_{B 50}$ is the percentage of the watershed that was burned and has slope values in excess of 50 percent

(in percent),

$p c t_{\text {high }}$ is the percent of the drainage basin area burned at high severity (in percent),

Kfact is the dimensionless erosivity index for the soils in the basin obtained from STATSGO data

(Schwartz and Alexander, 1995), and

$\mathrm{r} 30$ is the 30-min rainfall accumulation for the design storm, in this case we use the 30-min rainfall intensity for a 10-yr recurrence interval storm (in $\mathrm{mm}$ ).

Probabilities predicted by the equation potentially range from 0 (least likely) to 100 percent (most likely). The predicted probabilities are assigned to one of five equal (20 percent) interval classes for cartographic display.

Debris-flow volumes are predicted using a multiple linear regression model (Gartner and others, 2008) which have been applied in nearby southern California burn areas between 2007 and 2009 (for example, Cannon and others, 2007; 2009). This model is used to estimate the volume of material that could issue from the mouth of the defined drainage basin in response to a storm of a given 
rainfall intensity. This model was based upon volume estimates from 53 debris-flow-producing drainage basins in seven burn areas in southern California and follows the equation:

$$
\ln V=3.41+(0.485 \times \sqrt{i 15})+\left(0.298 \times \log \left(h m 50_{k m}\right)\right)+(0.173 \times \sqrt{\text { ElevRange }}
$$

where:

ElevRange is the range (maximum elevation-minimum elevation) within the watershed (in meters), $h m 50_{k m}$ is the area of the watershed that was burned at high or moderate severity and has slope values

in excess of 50 percent (in $\mathrm{km}^{2}$ ), and

$i 15$ is the peak 15-min rainfall intensity for the design storm; in this case we use the 15-min rainfall intensity for a 10-yr recurrence interval storm (in $\mathrm{mm}$ ).

Volume estimates were classified in order of magnitude scale ranges 0-1,000 cubic meters $\left(\mathrm{m}^{3}\right)$; $1,000-10,000 \mathrm{~m}^{3} ; 10,000-100,000 \mathrm{~m}^{3 ;}$ and greater than $100,000 \mathrm{~m}^{3}$ for cartographic display.

\section{Debris-Flow Hazard Assessment}

We calculated the probability, predicted volume and combined hazard at the outlet of 73 drainage basins located within the Powerhouse burn area. Drainage basin areas range from 0.11-7.8 $\mathrm{km}^{2}$. Basin outlet locations, morphometric variables, rainfall characteristics and model predictions are listed in table 1. Debris-flow probability, predicted volume, and combined hazard represent the estimates at the outlet of each drainage basin. 
Table 1. Basin outlet locations (UTM Zone 11 NAD83, Meters), morphometric variables, rainfall characteristics and model predictions for the 73 defined watersheds in the Powerhouse burn area.

\begin{tabular}{|c|c|c|c|c|c|c|c|c|c|c|c|c|c|}
\hline $\begin{array}{c}\text { Basin } \\
\text { ID }\end{array}$ & $\begin{array}{l}\text { Basin } \\
\text { area } \\
\left(\mathrm{km}^{2}\right)\end{array}$ & $\begin{array}{l}\text { Basin } \\
\text { outlet } \\
\text { easting } \\
\text { (m) }\end{array}$ & $\begin{array}{l}\text { Basin } \\
\text { outlet } \\
\text { northing } \\
\text { (m) }\end{array}$ & $\begin{array}{c}\text { Elevation } \\
\text { range } \\
\text { (m) }\end{array}$ & $\begin{array}{l}\text { Percent of } \\
\text { basin burned } \\
\text { with slopes } \\
\text { greater than } \\
=50 \text { percent }\end{array}$ & $\begin{array}{l}\text { Area of } \\
\text { moderate } \\
\text { or high } \\
\text { severity } \\
\left(\mathrm{km}^{2}\right)\end{array}$ & $\begin{array}{l}\text { Percent of } \\
\text { basin } \\
\text { burned at } \\
\text { high } \\
\text { severity }\end{array}$ & $\begin{array}{l}\text { Average } \\
\text { K-factor }\end{array}$ & $\begin{array}{c}\text { 10-year } \\
\text { peak 15- } \\
\text { minute } \\
\text { intensity } \\
(\mathrm{mm} / \mathrm{hr})\end{array}$ & $\begin{array}{l}\text { 10-year } \\
30 \text {-minute } \\
\text { rainfall } \\
\text { accumulation } \\
(\mathrm{mm})\end{array}$ & $\begin{array}{c}\text { Probability } \\
\text { of debris } \\
\text { flow }\end{array}$ & $\begin{array}{l}\text { Predicted } \\
\text { volume } \\
\left(\mathrm{m}^{3}\right)\end{array}$ & $\begin{array}{c}\text { Combined } \\
\text { Relative } \\
\text { Hazard } \\
\text { Ranking } \\
\text { (1= Low, } \\
5=\text { High) }\end{array}$ \\
\hline 1 & 7.14 & 369158 & 3841871 & 326 & 0.3 & 0.00 & 0.0 & 0.21 & 51 & 18 & 3.3 & $1,000-10,000$ & 3 \\
\hline 2 & 4.21 & 369039 & 3845731 & 200 & 0.5 & 0.00 & 0.0 & 0.29 & 41 & 14 & 4.2 & $1,000-10,000$ & 3 \\
\hline 3 & 7.81 & 368079 & 3845821 & 480 & 1.4 & 0.12 & 1.5 & 0.22 & 49 & 17 & 4.9 & $10,000-100,000$ & 4 \\
\hline 4 & 1.21 & 366700 & 3845212 & 206 & 2.1 & 0.00 & 0.0 & 0.23 & 45 & 16 & 3.0 & $1,000-10,000$ & 3 \\
\hline 5 & 2.29 & 371340 & 3845237 & 175 & 0.0 & 0.00 & 0.0 & 0.29 & 41 & 14 & 4.0 & $0-1,000$ & 2 \\
\hline 6 & 4.45 & 364859 & 3844052 & 421 & 4.6 & 0.01 & 0.2 & 0.18 & 53 & 19 & 3.6 & $10,000-100,000$ & 4 \\
\hline 7 & 5.82 & 370629 & 3840791 & 311 & 1.2 & 0.02 & 0.3 & 0.18 & 51 & 18 & 2.7 & $1,000-10,000$ & 3 \\
\hline 8 & 4.83 & 372529 & 3840431 & 348 & 0.7 & 0.01 & 0.2 & 0.20 & 48 & 17 & 3.2 & $1,000-10,000$ & 3 \\
\hline 9 & 1.61 & 373089 & 3838961 & 263 & 4.6 & 0.00 & 0.0 & 0.18 & 48 & 17 & 2.6 & $1,000-10,000$ & 3 \\
\hline 10 & 0.78 & 373769 & 3838850 & 217 & 6.7 & 0.00 & 0.0 & 0.18 & 47 & 17 & 2.5 & $1,000-10,000$ & 3 \\
\hline 12 & 0.44 & 374599 & 3838641 & 264 & 3.4 & 0.00 & 0.0 & 0.18 & 45 & 16 & 2.5 & $1,000-10,000$ & 3 \\
\hline 13 & 0.69 & 374838 & 3838649 & 323 & 5.6 & 0.00 & 0.0 & 0.19 & 45 & 16 & 3.0 & $1,000-10,000$ & 3 \\
\hline 14 & 0.45 & 364739 & 3839719 & 193 & 22.3 & 0.01 & 1.2 & 0.18 & 56 & 20 & 3.5 & $1,000-10,000$ & 3 \\
\hline 15 & 1.19 & 366280 & 3838251 & 396 & 18.7 & 0.17 & 14.5 & 0.18 & 57 & 20 & 6.9 & $10,000-100,000$ & 4 \\
\hline 16 & 0.34 & 368648 & 3837411 & 193 & 10.0 & 0.02 & 6.2 & 0.18 & 55 & 19 & 3.1 & $1,000-10,000$ & 3 \\
\hline 17 & 0.52 & 369348 & 3837042 & 217 & 9.3 & 0.05 & 8.7 & 0.18 & 55 & 19 & 3.4 & $1,000-10,000$ & 3 \\
\hline 18 & 2.32 & 369738 & 3836961 & 366 & 3.3 & 0.04 & 1.6 & 0.18 & 55 & 19 & 3.3 & $10,000-100,000$ & 4 \\
\hline 19 & 0.32 & 370239 & 3836891 & 207 & 8.3 & 0.11 & 32.9 & 0.18 & 55 & 19 & 6.3 & $1,000-10,000$ & 3 \\
\hline 20 & 0.64 & 373197 & 3836551 & 167 & 0.2 & 0.00 & 0.0 & 0.18 & 49 & 17 & 1.9 & $0-1,000$ & 2 \\
\hline 21 & 0.78 & 366238 & 3836361 & 349 & 36.9 & 0.04 & 5.0 & 0.18 & 57 & 20 & 7.2 & $10,000-100,000$ & 4 \\
\hline 22 & 3.18 & 366659 & 3836571 & 432 & 18.9 & 0.40 & 12.7 & 0.18 & 56 & 20 & 7.0 & $10,000-100,000$ & 4 \\
\hline 23 & 1.28 & 366057 & 3836021 & 452 & 39.0 & 0.37 & 29.3 & 0.18 & 56 & 20 & 16.3 & $10,000-100,000$ & 4 \\
\hline 24 & 1.74 & 365669 & 3835663 & 465 & 46.8 & 0.64 & 36.6 & 0.18 & 56 & 20 & 22.6 & $10,000-100,000$ & 5 \\
\hline 25 & 0.72 & 364958 & 3835611 & 380 & 48.6 & 0.02 & 2.6 & 0.18 & 57 & 20 & 9.1 & $10,000-100,000$ & 4 \\
\hline 28 & 3.78 & 363768 & 3835111 & 537 & 52.4 & 0.19 & 5.1 & 0.18 & 59 & 21 & 13.8 & $10,000-100,000$ & 4 \\
\hline
\end{tabular}


Table 1. Basin outlet locations (UTM Zone 11 NAD83, Meters), morphometric variables, rainfall characteristics and model predictions for the 73 defined watersheds in the Powerhouse burn area.-Continued

\begin{tabular}{|c|c|c|c|c|c|c|c|c|c|c|c|c|c|}
\hline $\begin{array}{l}\text { Basin } \\
\text { ID }\end{array}$ & $\begin{array}{l}\text { Basin } \\
\text { area } \\
\left(\mathrm{km}^{2}\right)\end{array}$ & $\begin{array}{l}\text { Basin } \\
\text { outlet } \\
\text { easting } \\
\text { (m) }\end{array}$ & $\begin{array}{l}\text { Basin } \\
\text { outlet } \\
\text { northing } \\
\text { (m) }\end{array}$ & $\begin{array}{c}\text { Elevation } \\
\text { range } \\
\text { (m) }\end{array}$ & $\begin{array}{l}\text { Percent of } \\
\text { basin burned } \\
\text { with slopes } \\
\text { greater than = } \\
50 \text { percent }\end{array}$ & $\begin{array}{l}\text { Area of } \\
\text { moderate } \\
\text { or high } \\
\text { severity } \\
\left(\mathrm{km}^{2}\right)\end{array}$ & $\begin{array}{l}\text { Percent of } \\
\text { basin } \\
\text { burned at } \\
\text { high } \\
\text { severity }\end{array}$ & $\begin{array}{l}\text { Average } \\
\text { K-factor }\end{array}$ & $\begin{array}{c}\text { 10-year } \\
\text { peak 15- } \\
\text { minute } \\
\text { intensity } \\
(\mathrm{mm} / \mathrm{hr})\end{array}$ & $\begin{array}{l}\text { 10-year } \\
30 \text {-minute } \\
\text { rainfall } \\
\text { accumulation } \\
(\mathrm{mm})\end{array}$ & $\begin{array}{c}\text { Probability } \\
\text { of debris } \\
\text { flow }\end{array}$ & $\begin{array}{l}\text { Predicted } \\
\text { volume } \\
\left(\mathrm{m}^{3}\right)\end{array}$ & $\begin{array}{c}\text { Combined } \\
\text { Relative } \\
\text { Hazard } \\
\text { Ranking } \\
\text { (1= Low, } \\
5=\text { High) }\end{array}$ \\
\hline 29 & 1.08 & 363369 & 3834581 & 445 & 60.9 & 0.35 & 32.6 & 0.18 & 57 & 20 & 25.6 & $10,000-100,000$ & 5 \\
\hline 30 & 0.39 & 363269 & 3834522 & 423 & 39.4 & 0.21 & 54.4 & 0.18 & 57 & 20 & 27.5 & $10,000-100,000$ & 5 \\
\hline 31 & 0.43 & 362779 & 3834261 & 423 & 47.4 & 0.13 & 30.2 & 0.18 & 57 & 20 & 18.7 & $10,000-100,000$ & 4 \\
\hline 32 & 0.74 & 362288 & 3834131 & 411 & 50.6 & 0.30 & 40.7 & 0.18 & 57 & 20 & 24.4 & $10,000-100,000$ & 5 \\
\hline 33 & 0.38 & 362180 & 3834151 & 298 & 58.2 & 0.09 & 24.2 & 0.18 & 58 & 20 & 16.2 & $10,000-100,000$ & 4 \\
\hline 34 & 1.98 & 359944 & 3833751 & 475 & 23.7 & 0.36 & 17.9 & 0.18 & 58 & 20 & 9.7 & $10,000-100,000$ & 4 \\
\hline 35 & 0.21 & 359768 & 3833280 & 361 & 42.6 & 0.00 & 0.4 & 0.18 & 58 & 20 & 7.4 & $10,000-100,000$ & 4 \\
\hline 36 & 2.57 & 359356 & 3833117 & 486 & 39.4 & 0.42 & 16.3 & 0.18 & 57 & 20 & 12.9 & $10,000-100,000$ & 4 \\
\hline 37 & 2.28 & 357657 & 3830520 & 500 & 3.0 & 0.05 & 2.0 & 0.18 & 57 & 20 & 4.4 & $10,000-100,000$ & 4 \\
\hline 38 & 0.26 & 359410 & 3829964 & 400 & 30.9 & 0.11 & 42.0 & 0.18 & 55 & 19 & 17.3 & $10,000-100,000$ & 4 \\
\hline 40 & 0.54 & 361128 & 3829469 & 438 & 29.9 & 0.20 & 37.1 & 0.18 & 54 & 19 & 16.1 & $10,000-100,000$ & 4 \\
\hline 41 & 0.13 & 361049 & 3829670 & 214 & 27.9 & 0.01 & 9.8 & 0.18 & 55 & 19 & 5.2 & $1,000-10,000$ & 3 \\
\hline 42 & 0.82 & 360238 & 3829991 & 416 & 21.8 & 0.07 & 8.0 & 0.18 & 55 & 20 & 6.4 & $10,000-100,000$ & 4 \\
\hline 43 & 1.01 & 359868 & 3830051 & 496 & 33.1 & 0.33 & 32.6 & 0.18 & 54 & 19 & 17.0 & $10,000-100,000$ & 4 \\
\hline 44 & 0.25 & 359698 & 3830010 & 314 & 12.6 & 0.00 & 0.7 & 0.18 & 55 & 20 & 3.6 & $10,000-100,000$ & 4 \\
\hline 45 & 1.34 & 358898 & 3830241 & 469 & 25.6 & 0.05 & 3.4 & 0.18 & 56 & 20 & 6.8 & $10,000-100,000$ & 4 \\
\hline 46 & 3.67 & 362219 & 3830913 & 489 & 21.0 & 1.71 & 46.7 & 0.18 & 54 & 19 & 18.6 & $10,000-100,000$ & 4 \\
\hline 47 & 7.83 & 362218 & 3830952 & 514 & 18.5 & 1.73 & 22.1 & 0.18 & 56 & 20 & 10.3 & $10,000-100,000$ & 4 \\
\hline 48 & 1.43 & 362108 & 3830930 & 376 & 26.9 & 0.13 & 9.1 & 0.18 & 56 & 20 & 6.8 & $10,000-100,000$ & 4 \\
\hline 49 & 0.78 & 361668 & 3830451 & 326 & 27.6 & 0.13 & 16.3 & 0.18 & 56 & 20 & 7.6 & $10,000-100,000$ & 4 \\
\hline 50 & 1.00 & 364071 & 3828870 & 337 & 18.0 & 0.05 & 4.8 & 0.18 & 52 & 18 & 4.6 & $10,000-100,000$ & 4 \\
\hline 51 & 2.27 & 364290 & 3828901 & 582 & 25.1 & 0.17 & 7.6 & 0.18 & 53 & 19 & 9.1 & $10,000-100,000$ & 4 \\
\hline 52 & 0.19 & 364917 & 3828791 & 298 & 24.4 & 0.00 & 0.0 & 0.18 & 51 & 18 & 4.3 & $1,000-10,000$ & 3 \\
\hline 53 & 2.09 & 365819 & 3828641 & 674 & 30.2 & 0.05 & 2.3 & 0.18 & 51 & 18 & 10.3 & $10,000-100,000$ & 4 \\
\hline 56 & 1.33 & 367451 & 3830300 & 565 & 30.5 & 0.27 & 20.4 & 0.18 & 52 & 18 & 13.4 & $10,000-100,000$ & 4 \\
\hline
\end{tabular}


Table 1. Basin outlet locations (UTM Zone 11 NAD83, Meters), morphometric variables, rainfall characteristics and model predictions for the 73 defined watersheds in the Powerhouse burn area.-Continued

\begin{tabular}{|c|c|c|c|c|c|c|c|c|c|c|c|c|c|}
\hline $\begin{array}{l}\text { Basin } \\
\text { ID }\end{array}$ & $\begin{array}{l}\text { Basin } \\
\text { area } \\
\left(\mathrm{km}^{2}\right)\end{array}$ & $\begin{array}{l}\text { Basin } \\
\text { outlet } \\
\text { easting } \\
\text { (m) }\end{array}$ & $\begin{array}{l}\text { Basin } \\
\text { outlet } \\
\text { northing } \\
\text { (m) }\end{array}$ & $\begin{array}{c}\text { Elevation } \\
\text { range } \\
(\mathrm{m})\end{array}$ & $\begin{array}{l}\text { Percent of } \\
\text { basin burned } \\
\text { with slopes } \\
\text { greater than = } \\
50 \text { percent }\end{array}$ & $\begin{array}{l}\text { Area of } \\
\text { moderate } \\
\text { or high } \\
\text { severity } \\
\left(\mathrm{km}^{2}\right)\end{array}$ & $\begin{array}{l}\text { Percent of } \\
\text { basin } \\
\text { burned at } \\
\text { high } \\
\text { severity }\end{array}$ & $\begin{array}{l}\text { Average } \\
\text { K-factor }\end{array}$ & $\begin{array}{c}\text { 10-year } \\
\text { peak 15- } \\
\text { minute } \\
\text { intensity } \\
(\mathrm{mm} / \mathrm{hr})\end{array}$ & $\begin{array}{l}\text { 10-year } \\
30 \text {-minute } \\
\text { rainfall } \\
\text { accumulation } \\
(\mathrm{mm})\end{array}$ & $\begin{array}{c}\text { Probability } \\
\text { of debris } \\
\text { flow }\end{array}$ & $\begin{array}{l}\text { Predicted } \\
\text { volume } \\
\left(\mathrm{m}^{3}\right)\end{array}$ & $\begin{array}{c}\text { Combined } \\
\text { Relative } \\
\text { Hazard } \\
\text { Ranking } \\
\text { (1= Low, } \\
5=\text { High) }\end{array}$ \\
\hline 57 & 0.13 & 367409 & 3830011 & 249 & 25.0 & 0.00 & 0.0 & 0.18 & 51 & 18 & 3.9 & $1,000-10,000$ & 3 \\
\hline 58 & 0.63 & 367648 & 3830359 & 395 & 11.3 & 0.04 & 6.4 & 0.18 & 52 & 18 & 4.7 & $10,000-100,000$ & 4 \\
\hline 59 & 1.61 & 367768 & 3831711 & 534 & 34.9 & 0.75 & 46.6 & 0.18 & 54 & 19 & 25.2 & $10,000-100,000$ & 5 \\
\hline 60 & 0.60 & 360779 & 3829702 & 467 & 46.1 & 0.21 & 35.1 & 0.18 & 54 & 19 & 21.5 & $10,000-100,000$ & 5 \\
\hline 61 & 0.39 & 361407 & 3829410 & 317 & 8.8 & 0.04 & 11.1 & 0.18 & 54 & 19 & 4.4 & $10,000-100,000$ & 4 \\
\hline 62 & 0.24 & 368908 & 3837772 & 176 & 14.9 & 0.00 & 0.0 & 0.18 & 54 & 19 & 2.8 & $1,000-10,000$ & 3 \\
\hline 63 & 0.21 & 369030 & 3837712 & 167 & 11.6 & 0.00 & 0.0 & 0.18 & 54 & 19 & 2.6 & $1,000-10,000$ & 3 \\
\hline 64 & 0.55 & 369609 & 3837469 & 196 & 6.6 & 0.00 & 0.0 & 0.18 & 53 & 19 & 2.4 & $1,000-10,000$ & 3 \\
\hline 65 & 0.50 & 371149 & 3836432 & 227 & 0.6 & 0.03 & 5.2 & 0.18 & 54 & 19 & 2.6 & $1,000-10,000$ & 3 \\
\hline 66 & 0.52 & 370939 & 3836901 & 227 & 2.7 & 0.06 & 11.5 & 0.19 & 54 & 19 & 3.4 & $1,000-10,000$ & 3 \\
\hline 68 & 0.20 & 368558 & 3837661 & 148 & 9.0 & 0.01 & 6.4 & 0.18 & 55 & 19 & 2.8 & $1,000-10,000$ & 3 \\
\hline 69 & 0.13 & 368118 & 3837771 & 149 & 4.7 & 0.00 & 3.6 & 0.18 & 55 & 19 & 2.4 & $1,000-10,000$ & 3 \\
\hline 70 & 0.28 & 366838 & 3837581 & 172 & 10.1 & 0.02 & 7.3 & 0.18 & 55 & 19 & 3.1 & $1,000-10,000$ & 3 \\
\hline 71 & 0.18 & 366348 & 3836500 & 262 & 37.5 & 0.00 & 0.5 & 0.18 & 56 & 20 & 5.5 & $10,000-100,000$ & 4 \\
\hline 72 & 0.21 & 365938 & 3835921 & 280 & 25.5 & 0.00 & 0.0 & 0.18 & 57 & 20 & 4.4 & $10,000-100,000$ & 4 \\
\hline 73 & 0.23 & 358199 & 3830221 & 274 & 36.7 & 0.00 & 0.0 & 0.18 & 56 & 20 & 5.4 & $1,000-10,000$ & 3 \\
\hline
\end{tabular}




\section{Debris-Flow Probability Estimates}

Overall the model predicts relatively low probabilities of debris flow in response to a $10-y r$, 30-min rainstorm (plate 1). Seven of the 73 defined basins were identified as having a 20-40 percent likelihood of debris flow during the design storm. Five of these basins (Basins 24, 27, 29, 30, and 32) were located along Lake Hughes Road within Lake Canyon. Basin 59 (located in South Portal Canyon above the South Portal Truck Trail) and Basin 60 (located in Ruby Canyon) were also identified as having a 20-40 percent probability of debris flow in response to the design storm. All other basins were identified as having less than 20 percent probability of debris flow in response to the design storm.

\section{Debris-Flow Volume Estimates}

While the models predict a relatively low likelihood of debris flow, the consequences of debrisflow occurrence are quite high (plate 2). The volume model estimated that 44 of the 73 basins were capable of producing debris flows with potential volumes ranging from $10,000-100,000 \mathrm{~m}^{3}$. These basins were located primarily in Lake Canyon along Lake Hughes Road and in Ruby Canyon and South Portal Canyon above the South Portal Truck Trail. Twenty-seven of the 73 basins were identified as having debris flows with volumes ranging from 1,000-10,000 $\mathrm{m}^{3}$. These basins were located mainly within Pine Canyon above Elizabeth Lake Road and on the northeastern portion of the burn area draining towards Lancaster. Only one of the basins (Basin 5) was identified as having a predicted debris-flow volume less than $1,000 \mathrm{~m}^{3}$.

\section{Combined Relative Debris-Flow Hazard Rankings}

We combined the results of the probability and the volume maps following the methods of Cannon and others (2010) to obtain an estimate of the combined relative hazard of the drainage basins defined for the Powerhouse fire (plate 3). Forty-four of the 73 defined basins were identified as having a moderate hazard ranking. Within the moderate class, the higher scores (a score of 5 out of a possible 9) were identified for seven of the 73 defined basins. These basins coincided with those that were predicted to have the highest probabilities of debris flow, including Basins 24, 27, 29, 30, and 32 in Lake Canyon, Basin 59 in South Portal Canyon, and Basin 60 in Ruby Canyon. Thirty-seven of the basins were identified as having the second-highest combined hazard score (score of 4 out of a possible 9). These basins are located in the central and southwestern portion of the burn area, many of which drain directly onto Lake Hughes Road.

Low hazard rankings were identified for 29 of the defined basins. Within this class, 27 of the defined basin were found to have a moderate combined relative hazard ranking (a score of 3 out of a possible 9). These basins were situated above Lake Hughes and Lake Elizabeth and the communities in Pine Canyon. The remaining two basins (Basins 5 and 20) had the lowest combined score (a score of 2 out of a possible 9).

\section{Limitations of Hazard Assessments}

This assessment used a 10-yr recurrence interval storm to predict the probability, volume, and combined relative hazard of debris flows in basins burned by the 2013 Powerhouse fire in Los Angeles County, Calif. Differences in model predictions and actual debris-flow occurrence will arise with differences in actual storm duration and intensity. In addition, this study relies upon readily available geospatial data, the accuracy and precision of which may influence the estimated likelihood and magnitude of post-fire debris flows. However, local conditions, such as debris supply, certainly 
influence both the probability and volume of debris flows. Unfortunately, locally specific data is not presently available at the spatial scale of the post-fire debris-flow hazard assessment. As such, local conditions that are not constrained by the model may serve to dramatically increase or decrease the probability and(or) volume of a debris flow at a basin outlet. The input geospatial data are also subject to error based upon mapping resolution, elevation interpolation techniques and mapping and/or classification methods. Finally, this assessment is specific to debris-flow hazards; hazards from flashflooding are not described in this study and may be significant.

This assessment also characterizes potential debris-flow hazards at a static point in time immediately following wildfire. Studies of post-fire debris flows in southern California and the intermountain western United States have indicated that debris-flow activity in recently burned areas typically occurs within 2 yr of wildfire (Cannon and Gartner, 2005; Cannon and others, 2008; Gartner and others, 2008; Cannon and others, 2009). As vegetation cover and soil properties return to pre-fire conditions, the threat of debris-flow activity decreases with the amount of time elapsed since a wildfire. However, the hazards from flash-flooding may persist for several years after wildfire.

Finally, this work is preliminary and is subject to revision. It is being provided due to the need for timely "best science" information. The assessment is provided on the condition that neither the U.S. Geological Survey nor the Unites States Government may be held liable for any damages resulting from the authorized or unauthorized use of the assessment.

\section{Summary and Conclusions}

This assessment characterizes the post-fire debris-flow hazards that may exist within and below the 2013 Powerhouse fire near Lancaster, Calif. We use geospatial data related to basin morphometry, burn severity, soil properties, and rainfall characteristics to estimate the probability and predicted volume of debris flows that may occur in response to a 10 -yr recurrence interval rainstorm. We have identified that probabilities of debris-flow occurrence in response to the design rainstorm are relatively low, with only 7 of the 73 defined basins having a probability of debris-flow greater than 20 percent. Despite low probabilities, the predicted volume of potential debris flows may be large: 44 of the 73 basins were identified as capable of producing debris flows with volumes ranging from 10,000-100,000 $\mathrm{m}^{3}$. Combining the probability and volume models into a combined-hazard ranking indicates that 7 basins were of the greatest threat of post-fire debris-flow activity, obtaining a score of 5 out of possible 9. We have identified that Lake Canyon, Pine Canyon, Ruby Canyon, and South Portal Canyon are at greatest risk for hazards associated with post-fire debris flows. Moderate combined hazard rankings in the basins upstream of these locations indicate a significant possibility of debris-flow impact to homes, building, roads, bridges, culverts, and reservoirs located within and downstream of the burn area. We recommend that residents remain vigilant and take responsible actions to prevent injury or loss of life from post-fire debris flows and flash floods that may occur in response to high-intensity rainfall during short-lived summer convective thunderstorms and longer duration winter storms.

\section{References Cited}

Bonnin, G.M., Martin, D., Lin, B., Parzybok, T., Yekta, M., and Riley, D., 2006, Precipitation frequency atlas of the United States: Silver Spring, Md., National Weather Service, National Oceanic and Atmospheric Administration atlas 14, v. 1, version 5, accessed July 30, 2013, at http://hdsc.nws.noaa.gov/hdsc/pfds/.

Campbell, R.H, 1975, Soil slips, debris flows, and rainstorms in the Santa Monica mountains and vicinity, southern California: U.S. Geological Survey Professional Paper 851, 55 p. 
Cannon, S.H., Boldt, E.M., Laber, J.L., Kean, J.W., and Staley, D.M., 2011, Rainfall intensity-duration thresholds for postfire debris-flow emergency-response planning: Natural Hazards, v. 59, no. 1, p. 209-236.

Cannon, S.H., Boldt, E.M., Kean, J.W., Laber, J.L., and Staley, D.M., 2010, Relations between rainfall and postfire debris-flow and flood magnitudes for emergency-response planning, San Gabriel Mountains, southern California: U.S. Geological Survey Open File Report 2010-1039, 31 p.

Cannon, S.H., and DeGraff, J., 2009, The increasing wildfire and post-fire debris-flow threat in Western USA, and implications for consequences of climate change, chap. 9 of Sassa, K., and Canuti, P., eds., Landslides-Disaster Risk Reduction: Berlin, Springer, p. 177-190.

Cannon, S.H., and Gartner, J.E., 2005, Wildfire-related debris flow from a hazards perspective, chap. 15 of Jakob, M., and Hungr, O., eds., Debris-flow hazards and related phenomena: Chichester, U.K., Springer-Praxis Books in Geophysical Sciences, p. 321-344.

Cannon, S.H., Gartner, J.E., Michael, J.A., Bauer, M.A., Stitt, S.C., Knifong, D.L., MCnamara, B.J., and Roque, Y.M., 2007, Emergency assessment of debris-flow hazards from basins burned by the 2007 Buckweed Fire, Los Angeles County, Southern California: U.S. Geological Survey Open-File Report 2007-1414,1 sheet.

Cannon, S.H., Gartner, J.E., Rupert, M.G., Michael, J.A., Staley, D.M., and Worstell, B.B., 2009, Emergency assessment of postfire debris-flow hazards for the 2009 Station Fire, San Gabriel Mountains, southern California: U.S. Geological Survey Open File Report 2009-1227, 20 p. (Revised April 2010)

Cannon, S.H., Gartner, J.E., Wilson, R., Bowers, J., and Laber, J., 2008, Storm rainfall conditions for floods and debris flows from recently burned areas in southwestern Colorado and southern California: Geomorphology v. 96, no. 3-4, p. 250-269.

Eaton, E.C., 1935, Flood and erosion control problems and their solution: Proceedings of the American Society of Civil Engineers, v. 62, no. 8, p. 1302-1362.

Gabet, E., and Sternberg, P., 2008, The effects of vegetative ash on infiltration capacity, sediment transport, and the generation of progressively bulked debris flows: Geomorphology v. 10, no. 4, p, 666-673.

Gartner, J.E., Cannon, S.H., Santi, P., and Dewolfe, V., 2008, Empirical models to predict the volumes of debris flows generated by recently burned basins in the western U.S.: Geomorphology, v., 96, no. 3-4, p. 339-354.

inciweb.org, 2013, Mountain fire: InciWeb, accessed July 2013, at http://www.inciweb.org/incident/3516/\#.

Jennings, C.W., and Strand, R.G., 1969, Geologic map of California: Los Angeles Sheet, California Division of Mines and Geology, 1:250,000.

Kean, J.W., Staley, D.M., and Cannon, S.H., 2011, In situ measurements of post-fire debris flows in southern California - Comparisons of the timing and magnitude of 24 debris-flow events with rainfall and soil moisture conditions: Journal of Geophysical Research, v. 116, F4:F04019.

Larsen, I.J., MacDonald, L.H., Brown, E., Rough, D., Welsh, M.J., Pietraszek, J.H., Libohova, Z., de Dios Benavides-Solorio, J., and Schaffrath, K., 2009, Causes of post-fire runoff and erosion: Water Repellency, Cover, or Soil Sealing?: Soil Science Society of America Journal, v. 73, no. 4, p. 1393-1407.

McPhee, J.A., 1989, The control of nature: New York, Farrar, Straus and Giroux. 272p.

Remote Sensing Applications Center, 2013, BAER imagery support data download, USFS Region 5:

U.S. Department of Agriculture Forest Service, accessed July 2013 at

http://activefiremaps.fs.fed.us/baer/download.php. 
Rupert, M.G., Cannon, S.H., Gartner, J.E., Michael, J.A., and Helsel, D.R., 2008, Using logistic regression to predict the probability of debris flows in areas burned by wildfires, southern California, 2003-2006: U.S. Geological Survey Open File Report 2008-1370, 20 p.

Schwartz, G.E., and Alexander, R.B., 1995, Soils data for the conterminous United States derived from the NRCS State Soil Geographic (STATSGO) Database: U.S. Geological Survey Open-File Report 95-449, accessed July 2013 at http://water.usgs.gov/GIS/metadata/usgswrd/XML/ussoils.xml.

Shakesby, R., and Doerr, S., 2006, Wildfire as a hydrological and geomorphological agent: EarthScience Reviews, v. 74, no. 3-4, p. 269-307.

Staley, D.M., Kean, J.W., Cannon, S.H., Schmidt, K.M., and Laber, J.L., in press, Objective definition of rainfall intensity-duration thresholds for the initiation of post-fire debris flows in southern California: Landslides, p. 1-16. 